ФОРМУВАННЯ ЛІДЕРСЬКИХ ЯКОСТЕЙ У МАЙБУТНІХ УЧИТЕЛІВ МАЙБУТНЬОГО МИСТЕЦТВА В ДИРИГЕНТСЬКО-ХОРОВОМУ АСПЕКТІ НА ПРИКЛАДІ ОДЕСЬКОЇ ХОРОВОЇ ШКОЛИ

\title{
FORMATION OF LEADERSHIP QUALITIES IN FUTURE TEACHERS OF FUTURE ART IN CONDUCTING AND CHORAL ASPECT ON THE EXAMPLE OF ODESSA CHORAL SCHOOL
}

УДК 378:37.011.3-051:7.071.2:316.46 DOI https://doi.org/10.32843/2663$6085 / 2021 / 37.3$

\section{Гетманець Н.Ю.,} аспірантка фракультету просресійної освіти, асистент кафедри диригентсько-хорової підготовки Південноукраїнського національного педагогічного університету імені К.Д. Ушинського

\section{Линенко А.Ф.,} профресор кафредри просресійної підготовки Південноукраїнського національного педагогічного університету імені К.Д. Ушинського
Стаття присвячена актуальній проблемі підготовки майбутніх учителів музичного мистецтва - фрормуванню лідерських якостей у контексті диригентсько-хорової підготовки. у статmі розглядаються такі основні теоретичні засади до фоомування лідерських якостей у майбутніх учителів музичного мистецтва в диригентськохоровому аспекті, як володіння широким спектром професійних компетентностей, зокрема, курс диригентсько-хорової підготовки. Виявлено фрактори наявності лідерських якостей у системі хормейстерської підготовки майбутнього вчителя музичного мистецтва.

Виокремлено декілька типів лідерів за різними науково-педагогічними підходами сучасних науковців Одеської хорової школи як яскравого представника міжнародного хорового руху. Виявлено основні критеріі формування лідерських якостей у майбутніх учителів музичного мистецтва в системі диригентсько-хорової підготовки. Встановлені основні складники, які впливають на успішність взаємодії керівника хорового колективу з учасниками хору.

Висвітлено основні риси творчої та педагогічної взаємодії між керівником, хористами та слухачем. Виокремлено основні персоналії встановлення Одеської хорової школи як окремої мистецько-виконавської школи в системі музично-педагогічної освіти. Висвітлено постать хормейстера-диригента К. Пігрова та його послідовників у персоналіях. Виявлено основні педагогічні принципи в роботі К. Пігрова з хоровим колективом як фунндаментальний підхід до фрормування лідерських якостей майбутнього вчителя музики в процесі диригентсько-хорової підготовки. Узагальнено основні педагогічні принципи роботи з учнями та студентами продовжувача традицій К. Пігрова Д. Загрецького.

Виявлено нові вимоги до майбутнього керівника хорового колективу - опанування нових суміжних видів педагогічної діяльності. Встановлено основні методи фоормвання лідерських якостей у майбутніх учителів музичного мистецтва в процесі диригент сько-хорової підготовки.

Ключові слова: лідерство, лідерські якості, диригентсько-хорова підготовка, Одеська хорова школа, управлінець.

The article is devoted to the topical problem of training future teachers of music art - the formation of leadership qualities in the contex of conducting and choral training. The article considers such basic theoretical principles for the formation of leadership qualities in future teachers of music in the conducting and choral aspect, as the possession of a wide range of professional competencies, in particular, the course of conducting and choral training. Factors of presence of leadership qualities in the system of choral training of the future teacher of musical art are revealed. Several types of leaders have been identified according to different scientific and pedagogical approaches of modern scientists of the Odessa choral school as a bright representative of the international choral movement choir with choir members.

The main features of creative and pedagogical interaction between the leader, choristers and listener are highlighted. The main personalities of establishing the Odessa choral school as a separate art and performing school in the system of music and pedagogical education are highlighted. The figure of choirmaster-conductor $K$. Pigrov and his followers in personalities is covered. The basic pedagogical principles in the work of $K$. Pigrov with the choir as a fundamental approach to the formation of leadership qualities of the future music teacher in the process of conducting and choral training are revealed. The basic pedagogical principles of work with pupils and students of the successor of traditions K. Pigrov - D. Zagretsky are generalized. New requirements to the future leader of the choir - mastering new related types of pedagogical activities. The basic methods of formation of leadership qualities in future teachers of music art in the process of conducting and choral training are established.

Key words: leadership, leadership qualities, conducting and choral training, Odessa choral school, manager.
Постановка проблеми в загальному вигляді. Сучасні тенденції розвитку музично-педагогічної освіти вимагають від майбутніх фрахівців, окрім достатньої фрахової підготовки та високого рівня компетентності, яскравого прояву лідерських якостей, що спрямовано на більш якісну взаємодію в освітньому процесі.

Важливо зазначити, що сучасна підготовка майбутнього вчителя музичного мистецтва передбачає оволодіння широким спектром професійних компетентностей: знаннями, уміннями, навичками у ссрері музично-інструментальної, теоретично- історичної, вокальної, музично-теоретичної та диригентсько-хорової підготовки. Остання включає в себе курс диригентсько-хорової майстерності, практикум роботи з вокальним ансамблем, хоровий клас. Зазначене вимагає від викладачів різних спеціальностей однієї стратегії фрормування музичних компетентностей у майбутніх фахівців, сутність якої полягає в досягненні головної мети - підготовці висококваліфікованих фрахівців даної сорери. Як показує педагогічна практика, значна роль в оволодінні професійною компетентністю майбутніх учителів музичного мистецтва 
належить не тільки когнітивно-діяльнісній підготовці, а й розвитку широкого кола профресійно значущих якостей. Серед них - лідерські якості.

Аналіз останніх досліджень та публікацій. Окремі аспекти фрормування лідерських якостей розглядались як вітчизняними, так і зарубіжними вченими в різних напрямах: фрілософському (М. Вебер, Ф. Вольтер, Г. Гегель, Т. Гоббс, А. Курбський, Н. Макіавелі), педагогічному (Є. Горохова, Н. Кічук, Мараховська, А. Макаренко, М. Рожков, Н.С. Тітова), у галузі музичної освіти (Р. Гелготієне, Б. Тараканов).

Проблема лідерства досліджувалась психологами А. Адлером, 3. Фрейдом, К. Юнгом, серед українських психологів - це Н. Анікєєва, І. Волков, Т. Гура, В. Зацепін, Я. Коломінський, Р. Кричевський, А. Лутошкін, А. Петровський, О. Пономарьов, О. Романовський, Л. Уманський та ін.

Науковці цієї сорери визначали їх вплив на ефрективність якості професійної діяльності. Так, C. Максименко стверджує, що лідерські якості формуються за трьома напрямами концепції лідерства - обґрунтування переваги фрактора рис особистості, фрактора фрормування лідерських якостей за ситуацією та поєднання цих двох факторів [5].

Мета статті - розглянути історичний аспект формування лідерських якостей майбутніх учителів музичного мистецтва в процесі диригентськохорової підготовки на прикладі засновників Одеської хорової школи та визначити основні методи формування лідерських якостей майбутніх учителів музичного мистецтва в процесі диригентськохорової підготовки.

Вважаємо, що провідне місце в фрормуванні лідерських якостей у системі освітньої підготовки майбутнього вчителя музичного мистецтва $€$ курс диригентсько-хорової підготовки, який включає в себе кілька профрільних дисциплін, пов'язаних однією метою - виховання компетентного хорового диригента, який здатний продуктивно працювати в закладах вищої освіти.

Важливість наявності лідерських якостей у системі диригентсько-хорової підготовки зумовлена кількома фракторами:

- специфрікою профресії з позиції управлінської діяльності;

- постійною взаємодією 3 хоровим колективом, який складається зі студентів різного рівня підготовки, музичних здібностей, уваги та ін.;

- прагненням до самовдосконалення в майбутній професійній діяльності в різних проявах;

- необхідністю самопрезентації, роботою над self-management;

- високим рівнем самоефективності.

М. Грушевський виокремив такі типи лідерів це лідер-утопіст та лідер-цинік. Такого висновку учений дійшов у процесі дослідження амораль- ності в політиці. Лідером утопістом М. Грушевський вважав людину, чиї мрії та плани не мають підкріплення в реальному житті, а лідером-циніком - людину, позбавлену будь-яких моральних устоїв та ідеалів [3].

Л. Уманський зафіксував типи лідерів: лідерорганізатор (інтегратор процесу), лідер-ерудит (людина, яка володіє обширною системою знань), лідер-генератор емоційного настрою (формує настрій колективу), лідер-майстер (фрахівець в окремому виді діяльності) [7].

В. Шапар розрізняє типи лідерів за такими принципами:

- за змістом діяльності - це може бути лідернатхненник або лідер-виконавець;

- за характером діяльності - автор поділяє лідер на універсального та ситуативного;

- за спрямованістю дій - емоційний лідер або лідер діловий [8, с. 230].

При цьому лідер та керівник не обов'язково мають поєднуватися в одній особі. Лідер, на відміну від керівника, висувається стихійно.

Педагогічна практика показує, що наявність лідерських якостей необхідна учителям музичного мистецтва, перш за все, в діяльності керівника хорових колективів, який координує роботу групи. За своєю природою лідерські якості становлять основу професійної діяльності керівника зазначених колективів як управлінця, яка ускладнюється тим, що професійна комунікація протікає у специфрічних умовах групи, де сорери освіти та творчого процесу обмежені багатьма фракторами, які породжують додаткові труднощі у формуванні самостійності та прагнення до саморозвитку в межах роботи хорового колективу.

Керівник хорового колективу має навчати учнів музичної грамоти, навичок співу в хоровому колективі, практичних умінь у диригентсько-хоровому аспекті, формувати в них уміння й навички ефрективної управлінської комунікації, розвивати здатність організовувати взаємодію людей різних типів темпераменту, ментальність, підвищувати їхній рівень музичної підготовки, направляти їхню професійну діяльність, поведінку до бажаного результату з раціональним використанням соціально-психологічних характеристик комунікативної ситуації. Відомо, що в діяльності хормейстера поєднуються сенсорні, сугестивні, мовні, рухові, інтелектуальні уміння та навички ефективного міжособистісного спілкування та взаємодії.

Лідерські якості майбутнього вчителя музичного мистецтва розуміємо як особистісне інтегральне утворення, спрямоване на успішну взаємодію 3 учасниками хорових колективів, що визначається сукупністю складників: відповідальність, потреба до дії, впевненість у собі, рішучість та наполегливість, креативність, емоційний інтелект та здатність до саморефрлексії. Успішність формування 
лідерських якостей майбутніх учителів музичного мистецтва визначається сорормованістю професійних знань, умінь, навичок, спрямованих на успішну взаємодію з учасниками хорових колективів, що визначається вибором особистістю продуктивних дій для успішного вирішення поставлених цілей і завдань у контексті диригентсько-хорової підготовки.

У галузі музичного мистецтва в хоровому конструкті більш вживаним є поняття керівника або управлінця, що включає в себе також поняття лідера, творця, художнього керівника, хормейстера. Тому для повнішого освітлення досліджуваної проблеми приймемо більш притаманне фрормулювання - керівник хорового колективу або хормейстер (хормейстер-диригент).

Загальними рисами, притаманними кожному 3 представників цієї школи, є активне співавторство та взаємодія керівника хорового колективу, учасників колективу та слухача. Також важливо зазначити, що кожен реалізований у виконавському аспекті диригент також виховав як педагог велику кількість висококласних професіоналів, які достойно підтримують та продовжують традиції Одеської хорової школи не лише у виконавському, але і в педагогічно-виховному аспекті.

Значну роль у створенні авторської виконавської школи відіграли одеські музиканти (А. Авдієвський, Л. Бутенко, Д. Загрецький, Г. Ліознов, К. Пігров та ін.).

Основними педагогічними принципами роботи К. Пігрова був комплексний підхід у навчанні та вихованні студентів як музикантів і особистостей. К. Пігров вважав, що базою педагогічного процесу $€$ повна свідомість сприйняття вивченого матеріалу хорових творів та художня зацікавленість адекватної інтерпретації хорових творів. Великий педагог вважав, що керівник хорового колективу має володіти такими якостями, як емоційна стабільність, яскрава вольова позиція, музична чутливість, дисциплінованість. Його стиль як диригентахормейстера визначався наявністю лідерських якостей, які виражались у високій організованості колективу, творчій взаємодії між членами хорового колективу, майстерному рівні володіння широким спектром музичних прийомів та знань.

К. Пігров вважав, що ключовими аспектами в успішному звучанні хорового колективу $є$ :

- чистота інтонації;

- виховання голосу співака за допомогою систематичних та правильно побудованих занять;

- розвиток рухливості та гнучкості голосу за допомогою зразків хорової літератури;

- виховання естетичного та художнього смаку у співаків.

На думку К. Пігрова, інтонація є наріжним каменем, на якому будується хорове мистецтво та за допомогою якої досягається ансамблева співзвуч- ність. За методом митця, хоровий ансамбль досягається завдяки кропіткій роботі та особистісному підходу, який застосовується в роботі з окремою групою голосів.

К. Пігров дотримувався думки, що для мінімального ансамблевого співу потрібно три співака в партії. Завдяки цьому можна досягнути ланцюгового дихання, що є специфрічною здатністю хорового музикування і вимагає створення особливих музичних та психологічних умов. На думку автора, спів у хорі загалом провокує утворення лідерів та ведених у кожній партії, але головною метою керівника хору $є$ фрормування та виховання в кожного учасника хорового колективу лідерських якостей.

Учень та послідовник К. Пігрова - Д. Загрецький підтримував та продовжував педагогічні принципи свого наставника і вважав, що важливими фракторами педагогічної діяльності хормейстера $€$ вміння організувати хоровий колектив, «запалити» своєю ідеєю інтерпретації та мистецької думки велику групу людей, вирощувати в собі диригентську волю та вміння бути собою, не боятися розкритись як особистість перед іншими людьми. Він вважав, що хормейстер - це лідер не тільки як організатор, управлінець хорового колективу, але й лідер-інтерпретатор хорових творів, який може продемонструвати якісну інтерпретацію виконання та зрілий погляд на сутність, сенс музичного твору в рамках стильових особливостей епохи, в якій написано музичний твір.

Основним педагогічним принципом Д. Загрецького стало не виховання співака - учасника хору, а фрормування й виховання майбутнього диригента, диригента-хормейстера. Також важливо зазначити фракт фрормування Д. Загрецьким диригентської школи, яка відрізнялась музичністю, художньою виразністю та мистецькою свободою в інтерпретації та роботи з хоровим колективом.

3 позиції фрормування лідерських якостей у майбутніх учителів музичного мистецтва ми можемо зазначити вроджену здатність до привернення уваги та змоги «повести за собою» людей різних вікових категорій та складу характеру, що $є$ однією з ключових компетентностей майбутнього вчителя музичного мистецтва в контексті диригентсько-хорової підготовки за умови комплексної фрахової педагогічної роботи з майбутніми вчителями музичного мистецтва.

Роль лідера Д. Загрецький вважав також у переконанні при небагатослівності. Підтвердження цим словам можна знайти в його власному виразі: «Менше говорити - більше робити: від розмов ще жоден хор не заспівав» [2, с. 132].

В умовах сучасної роботи з хоровими колективами, коли від хору вимагається не лише статичне майстерне виконання музичних творів, а й привнесення в концертне звучання й елементів режисерської та хореографрічної постановки, керівник 
хорового колективу має опановувати суміжні види діяльності, крім мистецької, педагогічної, управлінської та музичної діяльності. Це призводить до створення нових умов та вимог до теоретичної бази в підготовці майбутнього вчителя музичного мистецтва в процесі диригентсько-хорової підготовки. Під цим розуміємо базові знання режисерської постанови, основні знання хореографрічних елементів та вміння їх пояснити та показати. Якщо ж колектив працює в межах спеціалізованого мистецько-педагогічного закладу освіти, то, як правило, в школі чи університеті має бути хореографр, якого можна долучити до реалізації сценічної постанови або ж запросити фрахівця 3 іншої профрільної установи.

Одеська хорова школа відома далеко за межами країни, про що говорить велика кількість концертуючих хорових колективів, постійна участь у міжнародних конкурсах, культурних обмінах та майстер-класах тощо.

Як зазначає $€$. Бондар, сучасні критерії конкурентоздатного хормейстера-лідера вимагають не тільки оснащеності в стилях виконавської майстерності, роботою 3 музичним текстом та вокально-хоровою роботою, але і здатністю «відчувати час». Підтвердження цьому твердженню ми можемо знайти в цитаті: «тому на сучасному нам етапі можна говорити про виявлення типу диригента, який синтезує у своїй творчості риси «біологічного» (або емоційного), раціонального (або відтворюючого), герменевтичного, театрального, медійно-режисерського типів (маємо на уваз можливість задуму хорових кліпів). Таким чином, сучасний диригент виявляє себе не лише як хормейстер, як диригент, але й як «музичний режисер», що володіє здатністю мислити сценою чи іншим публічним простором» [1, с. 306].

Таким чином, беручи за приклад педагогічні принципи засновників Одеської хорової школи, ми можемо сорормувати лідерські якості в майбутніх учителів музичного мистецтва в процесі диригентсько-хорової підготовки таким чином:

- діагностування студентів на виявлення лідерських якостей;

- навчання особистісно орієнтованому підходу в роботі з іншими людьми;

- донесення на власному позитивному прикладі необхідності до самовдосконалення;

- виховання адекватного критичного оцінювання власних результатів проведеної роботи;

- заповнення прогалин у музичному сприйнятті за допомогою презентації та обговорення зразкових творів світової музичної культури, як класичного періоду, так і сучасності;

- інтегрування в заняття 3 диригентсько-хорової підготовки навичок стратегічного та тактичного мислення на прикладі роботи над музичним твором у класі з концертмейстером;
- використання в заняттях практикуму роботи 3 вокально-хоровим ансамблем режисерської постанови та хореографрічних елементів та спонукання до створення цілісних режисерських постанов студентами;

- в роботі хорового класу виявлення та заохочення студентів у різних видах організаційної роботи хорового колективу, а саме:

а) ведення студентського журналу занять, в якому нотуються та аналізуються фррагменти творів, над якими працюють та описуються результати проведеного заняття;

б) організація та ведення обліку концертних костюмів хорового колективу;

в) допомога в організації забезпечення колективу нотним та методичним матеріалом для проведення занять;

г) введення в практику роботи з хоровим колективом студентів старших курсів, тобто проведення розспівок та ритмічних вправ із хоровим колективом під керівництвом художнього керівника хорового колективу;

ґ) залучення до режисування окремих музичних творів студентами;

д) залучення до обговорення важливих питань роботи 3 хоровим колективом: вибір концертної програми з програми колективу для виступів на окремих музичних заходах - фрестивалях, конкурcax, концертах, благодійних ярмарках, майстеркласах тощо;

е) залучення до організаторської та виконавської роботи з проведення майстер-класів, конфреренцій (волонтерська робота з координування та розміщення в аудиторіях та місцях проживання запрошених гостей та інших учасників заходу).

Висновки. Отже, узагальнення та систематизація типів лідерів у процесі диригентсько-хорової підготовки дозволило виявити основні чинники формування лідерських якостей у майбутніх учителів музичного мистецтва.

Розглянутий процес фрормування Одеської хорової школи на прикладі засновників говорить про синтез мистецької та педагогічно-виховної роботи з майбутніми учителями музичного мистецтва. Важливим чинником фрормування лідерських якостей вважаємо долучення та мотивування студентів до суміжних видів діяльності та заохочення активності учасників хорового колективу. Організувати та координувати продуктивну діяльність, спрямовану на фрормування необхідних вольових якостей, може забезпечити лише вмотивований та захоплений педагог, який є найбільш оптимальним для сфери педагогічного, виховного та мистецького виду діяльності.

Подальше дослідження зазначеної проблеми потребує розробки компонентно-структурного аналізу формування лідерських якостей майбутнього учителя музичного мистецтва у процесі диригентсько-хорової підготовки. 
БІБЛІОГРАФІЧНИЙ СПИСОК:

1. Бондар Є.М. Художньо-стильовий синтез як феномен сучасної хорової творчості. Одеса : Астроспринт, 2019. 388 с.

2. Бутенко Л.М. в классе Д.С. Загрецкого. Одесская консерватория. Забытые имена, новые страницы. Одесса : ОКФА, 1994. С. 130-135.

3. Сохань П., Гирич І., Панькова С. Грушевський М. Твори: у 50 т. Львів : Світ, 2005. C. 251-324.

4. Історія кафедри хорового диригування. ОНМА ім. А.В. Нежданової: вебсайт. URL: http://odma.edu.ua/ about/history/choral_conducting (дата звернення 18.06.2021).
5. Максименко С.Д. Лідерство як функцція професійної психологічної компетенції особистості. Проблеми сучасної психології. 2014. Випуск 24.

6. Пігров К.К. Керування хором. Москва : Музика, 1964. $220 \mathrm{c}$.

7. Уманский Л.И. Поэтапное развитие группы как коллектива. Коллектив и личность. Москва : Наука, 1975. $184 \mathrm{C}$

8. Шапар В.Б. Сучасний тлумачний психологічний словник. Харків : Прапор, 2005. 640 с.

9. Шпак Г. Корифей одеської хорової школи. OHMA ім. А.В. Нежданової: вебсайт. URL: https:// choircommunity.com.ua/koryfei-odeskoi-choir-school/ (дата звернення: 17.06.2021). 